\title{
Fitotelmata: Tempat Perindukan Nyamuk Terabaikan Selama Pandemi COVID-19
}

\author{
Hebert Adrianto $^{1^{*}}$ \\ ${ }^{1}$ Bagian Parasitologi, Fakultas Kedokteran Universitas Ciputra Surabaya \\ * Correspondence author: hebert.rubay@ciputra.ac.id; Tel.: 081235245620 \\ Received: 22 Februari 2021; Accepted: 8 Maret 2021; Published: 10 Maret 2021
}

\begin{abstract}
Abstrak
Demam Berdarah Dengue (DBD) berpotensi muncul saat musim hujan selama pandemi COVID-19. Demam Berdarah Dengue disebabkan oleh virus dengue, ditularkan oleh vektor nyamuk Aedes aegypti dan Aedes albopictus. Salah satu tempat perindukan alami nyamuk Aedes adalah tanaman fitotelmata. Tujuan tulisan ini adalah mengidentifikasi tanaman fitotelmata yang berpotensi menjadi tempat perindukan nyamuk. Tulisan ini merupakan studi literatur yang mengkaji artikel jurnal penelitian Indonesia dan artikel jurnal penelitian internasional yang relevan dengan topik. Hasil kajian menunjukkan bahwa tanaman fitotelmata yang berpotensi sebagai tempat perindukan nyamuk Aedes yang paling sering dilaporkan adalah tanaman hias bromelia (Bromelia sp, Neoregelia, dan Alcantarea), bambu (Bambusa sp., Gigantochloa), pisang (Musa paradisiaca), kelapa (Cocos nucifera), kelompok talas (Colocasia esculanta), talas belitung, kimpul, atau bentul (Xanthosoma sagittifolium), dan nanas (Ananas comosus). Dinas Kesehatan, Dinas Lingkungan/ Pertamanan Kota/ Tata Ruang Terbuka Hijau, arsitek lansekap, penjual tanaman, dan masyarakat perlu memperhatikan dan menangani tanaman fitotelmata yang berpotensi menjadi tempat perindukan nyamuk.
\end{abstract}

Kata kunci: Aedes, fitotelmata, tempat perindukan

\section{Pendahuluan}

Demam Berdarah Dengue (DBD) masih menjadi penyakit infeksi vektor penting dan endemis di Indonesia sepanjang tahun sampai saat ini. DBD disebabkan oleh virus dengue, yang ditularkan melalui perantaraan nyamuk Aedes aegypti sebagai vektor primer dan Aedes albopictus sebagai vektor sekunder (1). Pada tahun 2018, kasus kesakitan DBD di Indonesia berjumlah 65.602 kasus, dengan jumlah kematian sebanyak 467 orang (2). Pada tahun 2019, 
kasus DBD meningkat menjadi 138.127 kasus dan kasus kematian sebanyak 919 kasus. Penyakit ini disebabkan karena kepadatan populasi dan penyebaran vektor nyamuk yang tidak terkendali, ditambah mobilitas, kepadatan penduduk (3), dan perilaku masyarakat yang kurang menerapkan 4M Plus (4).

Di tahun 2020- Februari 2021 ini Indonesia bersama negara di seluruh dunia menghadapi masalah pandemi virus COVID-19 yang memakan banyak korban jiwa. Kebijakan pemerintah untuk mengurangi penyebaran COVID-19 adalah melalui pembatasan aktivitas di luar rumah dengan Kerja Dari Rumah atau Work From Home (WFH) (5). Dirjen P2P melalui surat edaran nomor HK.02.02/IV/2360/2020 menyampaikan bahwa ada peningkatan kasus di beberapa wilayah Indonesia sejak awal Januari 2020 dan di tengah pandemi COVID-19 sehingga diperlukan upaya pencegahan dan pengendalian DBD yang mengedepankan langkah preventif dan promotif (6).

Nyamuk Aedes aegypti dan Aedes albopictus menyukai air yang bersih dan jernih. Habitat nyamuk Aedes dikenal habitat alami (natural container) dan habitat buatan (artificial container). Habitat ini sering dikenal kontainer/ tempat penampungan air (TPA). Lokasi TPA ada yang di dalam rumah (indoor) maupun di luar rumah (outdoor). Widyatama (2018) melaporkan bahwa keberadaan tempat penampungan air sangat berperan terhadap ada tidaknya larva nyamuk. Semakin banyak ditemukan TPA maka akan berpotensi menjadi perindukan nyamuk sehingga akan semakin padat populasi larva nyamuk. Kepadatan populasi larva akan berlanjut ke tahap kepadatan populasi nyamuk dewasa Aedes dan pada akhirnya risiko terkena penyakit DBD lebih cepat (4). Pada bulan Desember 2020 hingga minggu pertama Februari 2021, Indonesia memasuki musim hujan. Hujan dengan curah hujan kecil dan waktu lama memiliki hubungan terhadap kejadian DBD karena keberadaan hujan mendukung terbentuknya tempat perindukan (breeding place) untuk nyamuk dewasa betina meletakkan telurnya serta meningkatkan kepadatan populasi nyamuk $(4,7)$. Setiap peningkatan $1 \mathrm{~mm}$ curah hujan dapat memberikan perubahan peluang peningkatan kasus DBD sebesar 0.131 kasus (7).

Salah satu tempat perindukan nyamuk yang perlu diperhatikan selama pandemi COVID19 adalah habitat alami (natural container), seperti tanaman fitotelmata. Fitotelmata dapat ditemukan di pekarangan rumah sebagai tanaman hias, tanaman obat, dan budidaya sayur maupun buahan. Dari hal ini ada kesenjangan antara manfaat tanaman dengan potensinya sebagai tempat perindukan nyamuk. Tujuan tulisan ini adalah mengidentifikasi tanaman fitotelmata yang berpotensi sebagai tempat perindukan nyamuk. 


\section{Material dan Metode}

Tulisan ini merupakan studi literatur dengan mengidentifikasi tanaman fitotelmata yang berpotensi sebagai tempat perindukan nyamuk. Sumber pustaka yang digunakan adalah artikel jurnal penelitian berbahasa Indonesia maupun artikel jurnal berbahasa Internasional. Penyajian tulisan dilakukan beberapa tahap, meliputi: 1) mengidentifikasi tanaman fitotelmata yang ditemukan larva nyamuk Aedes, 2) pembahasan dengan menganalisis faktor yang mendukung tanaman fitotelmata sebagai tempat perindukan nyamuk serta menyusun model pencegahan.

\section{Hasil}

Tanaman fitotelmata merupakan tanaman yang memiliki bagian tubuh atau bentuk yang dapat menampung genangan air $(8,9)$. Dari penelusuran artikel jurnal ditemukan ada 12 artikel jurnal penelitian dengan kata kunci fitotelmata, phytotelmata, fitotelmata Aedes, phytotelmata Aedes. Hasil analisis isi artikel yang sesuai dengan topik (kriteria inklusi) didapatkan lima artikel. Tujuh artikel lain tidak masuk dalam kriteria inklusi karena mengobservasi tanaman fitotelmata yang tergenang air tanpa mengkaji larva Aedes, selain itu ditemukan spesies nyamuk lain selain Aedes, belum dilakukan pengelompokan persentase berbagai spesies nyamuk stadium larva yang ditemukan per tanaman fitotelmata, lebih terfokus mengkaji virus dengue secara molekuler pada larva nyamuk yang ditemukan. Adapun hasil tanaman fitotelmata yang ditemukan larva nyamuk Aedes disajikan pada tabel berikut.

Tabel 1. Tanaman fitotelmata yang ditemukan larva nyamuk Aedes

\begin{tabular}{|c|c|c|}
\hline No & Tanaman fitotelmata & Penemu \\
\hline 1 & $\begin{array}{ll} & \text { Nanas } \\
\text { - } & \text { Talas } \\
\text { - } & \text { Bambu } \\
\text { - } & \text { Pandan }\end{array}$ & Rosa (9) \\
\hline 2 & $\begin{array}{l}\text { - Alcantarea imperialis (Carrière) Harms } \\
\text { - Neoregelia compacta (Mez) L. B. Sm. } \\
\text { - Neoregelia johannis (Carrière) L. B. Sm. } \\
\text { - Quesnelia quesneliana (Brongniart) L.B.Sm. }\end{array}$ & Mocellin et al. (10) \\
\hline 3 & $\begin{array}{l}\text { - Alocasia macrorrhiza } \\
\text { - Ananas comosus } \\
\text { - Areca catechu } \\
\text { - Cocos nucifera } \\
\text { - Colocasia esculenta } \\
\text { - Gigantochloa apus }\end{array}$ & Rosa et al. (11) \\
\hline
\end{tabular}




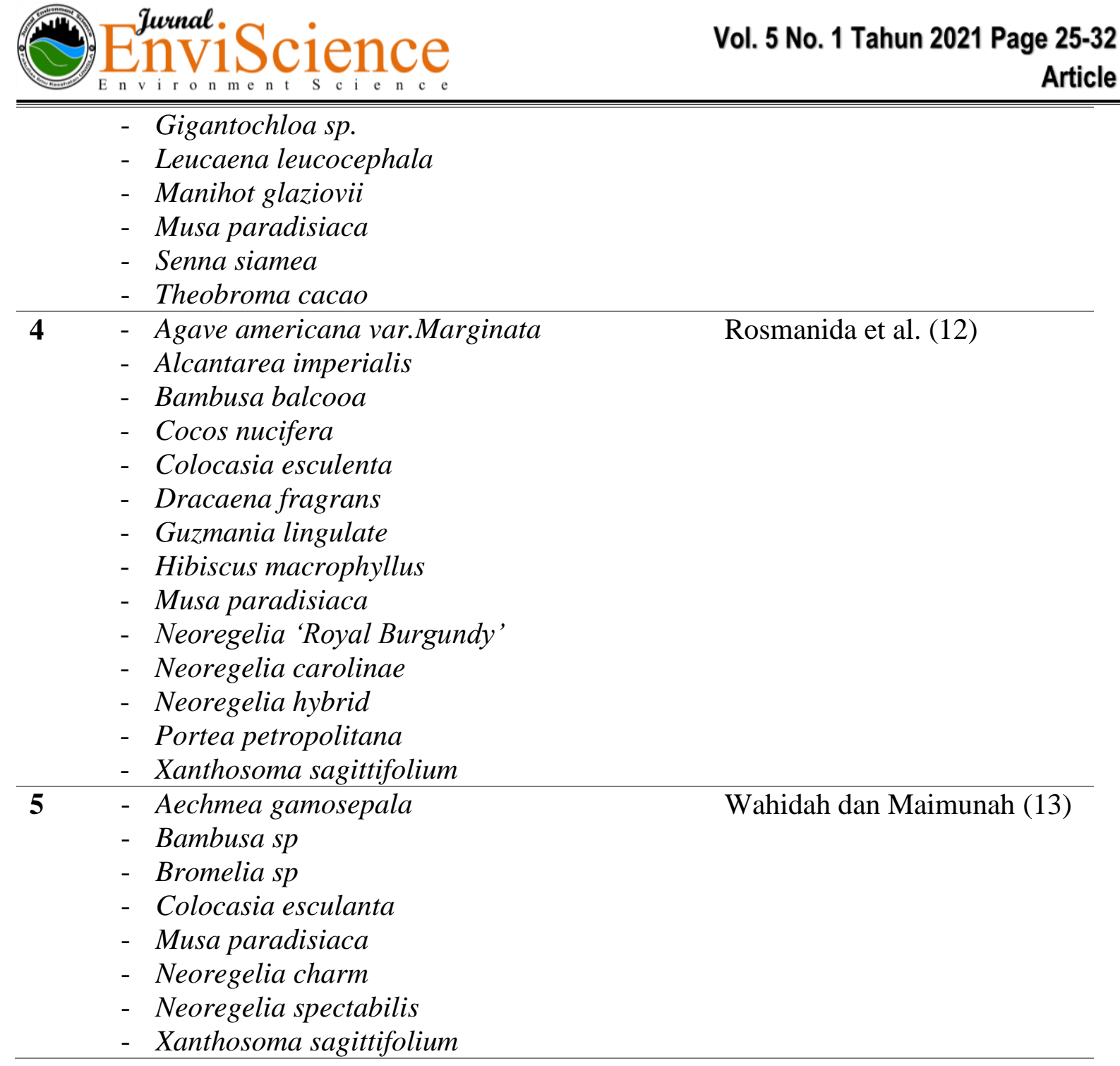

\section{Pembahasan}

Dari Tabel 1, didapatkan tanaman fitotelmata yang sama ditemukan oleh antar peneliti, seperti tanaman hias bromelia (Bromelia sp, Neoregelia, dan Alcantarea), bambu (Bambusa sp., Gigantochloa), pisang (Musa paradisiaca), kelapa (Cocos nucifera), kelompok talas (Colocasia esculanta), talas belitung, kimpul, atau bentul (Xanthosoma sagittifolium), dan nanas (Ananas comosus). Tanaman hias bromelia memiliki keanekaragaman spesies yang tinggi. Mocellin et al. (2009) melaporkan bahwa selain larva nyamuk Aedes, juga dapat ditemukan larva nyamuk yang lain pada tanaman hias bromelia (Neoregelia), seperti $C x$. (Mcx.) pleuristriatus, Runchomyia sp., Wy. (Pho.) incaudata, Wy. (Pho.) pilicauda, Wy. (Pho.) theobaldi, Wy. (Spi.) forcipenis, dan Toxorhynchites sp (10). Bagian tanaman ini yang menampung air sebagai tempat hidup nyamuk stadium larva dan pupa adalah ketiak daun (leaf axils) (12,13). Bagian bambu yang memiliki karakter fitotelmata adalah tunggul pohon atau lubang dalam pohon (tree stumps). Batang bambu yang dipotong akan membuka peluang 
datangnya nyamuk Aedes ke dalam lubang dalam dan bertelur di situ. Bagian tanaman pisang yang berpotensi sebagai fitotelmata adalah ketiak daun $(12,13)$. Cabang daun kelapa yang jatuh dan kering serta batok kelapa kering dan sudah jatuh ke tanah dapat menampung air (11). Daun talas (familia Araceae) dan nanas bagian ketiak daun dapat menampung air (8,11-13).

Sitinjak dkk (2020) juga melakukan observasi dan mendapatkan potensi fitotelmata juga dijumpai pada tanaman kantong semar (Nepenthes mirabilis), bunga bakung (Crynum asiaticum), pohon paku (Cyathea coopei), dan pohon pinang (Areca catechu). Pohon Cyathea coopei yang telah ditebang menghasilkan lubang paling besar di antara tanaman fitotelmata yang diobservasi (8). Rosa dkk (2017) juga melaporkan fitotelmata potensial meskipun dalam penelitiannya tidak ditemukan larva Aedes, seperti ketiak daun Alocasia spp., Dieffenbachia amoena, Dracaena fragrans, Sanseviera trifasciata, Guzmania sanguinea, Pandanus amaryllifolius, lubang permukaan batang (tree hole) pada Mangifera indica, Cerbera manghas, Jatropha curcas, Hevea brailiensis, Acacia mangium, Archidendron pauciflorum, Gnetum gnemon, Hibiscus tiliacius, Averrhoa carambola, Pyracantha angustifolia, Nephelium lappaceum, dan Filicium decipien (11). Lubang permukaan batang (tree hole) pada Manihot glaziovii, Leucaena leucocephala, Senna siamea, dan Theobroma cacao dilaporkan memiliki daya tampung air sebesar 14,5- $126 \mathrm{~mL}$ dan dijumpai larva nyamuk Ae. albopictus paling banyak 16 ekor (11). Spesies nyamuk yang dilaporkan paling banyak jumlahnya dari observasi fitotelmata adalah Ae. albopictus (10-13). Keberadaan larva nyamuk Aedes aegypti hanya dilaporkan minimal 2 ekor (10) dan paling banyak 23 ekor (12).

Faktor yang mendukung tanaman sebagai tempat perindukan nyamuk adalah karakter yang dimiliki oleh tanaman fitotelmata, seperti ketiak daun (leaf axils), tunggul pohon atau lubang dalam pohon (tree stumps), daun kering, struktur batok kelapa, lubang pohon (tree hole) $(9,11,14)$. Faktor air dari curah hujan (7) dan aktivitas manusia menyiram tanaman. Air akan masuk mengisi lubang yang tersedia (8). Dalam jumlah yang banyak akan membentuk genangan air. Nyamuk Aedes akan bertelur di permukaan dalam dekat genangan air (15). Telur Aedes akan menetas menjadi larva apabila telur terendam oleh air. Siklus nyamuk berlanjut dari larva menjadi pupa, kemudian menjadi nyamuk dewasa (imago) (16).

Dari temuan ini, cara memutus siklus hidup nyamuk agar tidak bertelur pada tanaman fitotelmata selama pandemi COVID-19 dan musim hujan adalah tidak meletakkan tanaman fitotelmata di luar ruangan/ pekarangan yang terkena hujan, berkomitmen rajin memantau dan membuang genangan air hujan yang dijumpai pada fitotelmata, tidak menebang pohon yang membentuk lubang dalam pohon, memusnahkan ranting/ cabang/ daun kering dan batok 
kelapa, atau menanam/ memelihara tanaman non fitotelmata. Upaya ini perlu melibatkan komitmen dan kerjasama banyak elemen, seperti Dinas Kesehatan, Dinas Lingkungan/ Pertamanan Kota/ Tata Ruang Terbuka Hijau, arsitek lansekap, penjual tanaman, dan masyarakat agar tidak hanya terfokus pada aspek pemanfaatan tetapi juga aspek preventif (pencegahan).

\section{Kesimpulan}

Tanaman fitotelmata yang berpotensi sebagai tempat perindukan nyamuk Aedes paling sering dan banyak dilaporkan adalah tanaman hias bromelia (Bromelia sp, Neoregelia, dan Alcantarea), bambu (Bambusa sp., Gigantochloa), pisang (Musa paradisiaca), kelapa (Cocos nucifera), kelompok talas (Colocasia esculanta), talas belitung, kimpul, atau bentul (Xanthosoma sagittifolium), dan nanas (Ananas comosus).

\section{Daftar Pustaka}


1. Pramestuti N, Djati AP. Distribusi Vektor Demam Berdarah Dengue (DBD) Daerah Perkotaan dan Perdesaan di Kabupaten Banjarnegara. Bul Penelit Kesehat. 2013;41(3):163-70.

2. Kementerian Kesehatan Republik Indonesia. Profil Kesehatan Indonesia 2018. Jakarta: Kementerian Kesehatan Republik Indonesia; 2019.

3. Kementerian Kesehatan Republik Indonesia. Profil Kesehatan Indonesia Tahun 2019. Jakarta: Kementerian Kesehatan Republik Indonesia; 2020.

4. Widyatama EF. Faktor Risiko yang Berpengaruh Terhadap Kejadian Demam Berdarah Dengue di Wilayah Kerja Puskesmas Pare. J Kesehat Lingkung. 2018;10(4):417-23.

5. Wahyu AM, Sa'id, Mochammad. Produktivitas Selama Work From Home : Sebuah Analisis Psikologi Sosial. J Kependud Indones. 2020;2902(Edisi Khusus Demografi dan Covid-19):53-60.

6. Direktur Jenderal P2P. Surat Edaran Nomor HK.02.02/IV/2360/2020 Tentang Pelaksanaan Pencegahan dan Pengendalian DBD dalam Situasi Pandemi Covi-19 [Internet]. Jakarta: Direktur Jenderal P2P; 2020. p. 1-2. Available from: https://covid19.kemkes.go.id/protokol-covid-19/pelaksanaan-pencegahan-danpengendalian-dbd-dalam-situasi-pandemi-covid-19/

7. Nisaa A. Korelasi Antara Faktor Curah Hujan Dengan Kejadian DBD Tahun 2010-2014 Di Kabupaten Karanganyar. Ikesma. 2018;14(1):25-33.

8. Sitinjak MA, Rosa E, Agustrina R, Sutyarso. Karakteristik dan Pola Sebaran Phytotelmata Sebagai Tempat Perindukan Alami Nyamuk di Kebun Raya Liwa Lampung Barat. Biospecies. 2020;13(2):16-21.

9. Rosa E. Kepadatan dan Distribusi Larvae Diptera Pada Phytotelmata di Daerah Endemis Demam Berdarah Dengue di Sumatera Barat. J Ilm Biol Eksperimen dan Keanekaragaman Hayati. 2014;2(2):73-6.

10. Mocellin MG, Simões TC, Nascimento TFS do, Teixeira MLF, Lounibos LP, Oliveira RL de. Bromeliad-Inhabiting Mosquitoes in An Urban Botanical Garden of Dengue Endemic Rio de Janeiro. Are Bromeliads Productive Habitats for The Invasive Vectors Aedes aegypti and Aedes albopictus? Mem Inst Oswaldo Cruz [Internet]. 2009;104(8):1171-1176. Available from: https://www.ncbi.nlm.nih.gov/pmc/articles/PMC3624763/pdf/nihms412728.pdf

11. Rosa E, Kanedi M, Okatviani PM, Ningsih WN. Phytotelmata Might Account for The High Prevalence of Dengue Hemorrhagic Fever in Lampung, Indonesia. Adv Life Sci. 
2017;7(2):15-20.

12. Rosmanida R, Fauziyah S, Pranoto AP. Physicochemical Characters of Mosquitoes Natural Breeding Habitats: First Record in High Dengue Hemorrhagic Fever Cases Area, East Java, Indonesia. J Trop Biodivers Biotechnol. 2020;5(2):100.

13. Wahidah FF, Maimunah U. Identifikasi Phytotelmata Yang Digunakan Sebagai Tempat Perindukan Aedes spp. di Kediri Jawa Timur. J Mat Sains. 2003;1(1):16-21.

14. Mangudo C, Aparicio JP, Rossi GC, Gleiser RM. Tree Hole Mosquito Species Composition and Relative Abundances Differ Between Urban and Adjacent Forest Habitats in Northwestern Argentina. Bull Entomol Res. 2017;1-10.

15. Rosa E, Salmah S, Dahelmi, Syamsuardi. Jenis dan Tipe Phytotelmata Sebagai Tempat Perindukan Alami Nyamuk di Beberapa Lokasi di Sumatera Barat. Pros SNSMAIP III2012. 2012;149-53.

16. Yulidar Y, Wilya V. Siklus Hidup Aedes aegypti Pada Skala Laboratorium. Sel. 2015;2(1):22-8. 